\title{
Human Enhancement Technologies:
}

\author{
New Hope or Threat to Society?
}

Jean-Aymeric Marot*

The Western world has undergone a paradigm shift over the course of the last 50 years, whereby individuals have increasingly gained control over their own body and life choices. Meanwhile, new technologies have increased their breadth of application, progressively blending into manifold aspects of our daily life. Human enhancement technologies in particular will bring a new set of risks and opportunities that may significantly disrupt the health and employment sectors, leading us to rethink our approach to science and the human body.

\section{Introduction}

Our relationship with technology has changed dramatically over the past five decades. It has become an integral part of our daily life; today we are able to buy groceries on the internet, check our bank accounts on our smartphone or smoke chemically flavoured e-cigarettes. However, we do not think of high-tech everyday items becoming parts of our bodies... yet.

This might change in the coming years, with the advent of human enhancement technologies (HETs). An enhancement is 'an intervention - a human action of any kind - that improves some capacity (or characteristic) that normal human beings ordinarily have or, more radically, that produces a new one.' HETs come in all shapes and sizes, from prosthetics to genetic engineering, and are bound to spark debate between the proponents of a right to self-ownership and those advocating a more traditional view of the sanctity of the human body.

This article will first address the growing importance of personal autonomy and control over one's own body in modern society through a human rights lens. Then, will demonstrate how HETs challenge the very notion of health as we understand it. The article will conclude with a closer look at genetic enhancements and the various issues they raise.

\section{The Rise of Personal Autonomy}

In essence, personal autonomy is the power to make choices in regard to our own bodies. It is what enables us to display our tastes, our personality, and it should not be taken for granted. For example, dicta- torships and authoritarian regimes tend to restrict body freedoms, either by way of prohibition or compulsion. Fallacious, sometimes dangerous ideologies often lay the ground for state programs that remove people's most basic liberties. In a not-so-distant past, those types of policies led to slavery by colonial powers, state-backed eugenics in Nazi Germany and coerced sterilisation of indigenous women in Canada. In such settings, the introduction and use of HETs could have devastating effects because they would essentially negate the ability for individuals to express any kind of choice.

Nevertheless, optimists may argue that times have changed. Human rights standards keep improving globally, civil liberties have increased, and the progressive empowerment of individuals has enabled them to regain control over their own bodies. But to what extent do we actually exercise this control? Depending on the applicable legal system, the answer may vary.

In the United States, citizens have traditionally enjoyed a high degree of freedom with regards to decisions affecting their body, their beliefs or more generally their lifestyle. This is a direct consequence from the importance given to the right to privacy. This right, which has achieved quasi-constitutional status since the landmark Supreme Court case Griswold $v$ Connecticut, essentially prevents public au-

DOI: 10.21552/delphi/2018/1/9

* Jean-Aymeric Marot holds a Master's degree in European Law from the Université catholique de Louvain (Belgium). For correspondence: <jean-aymeric.marot@outlook.com>

1 Allen Buchanan, Better Than Human - The Promise and Perils of Enhancing Ourselves (Oxford University Press 2011) 5 
thorities from interfering with the enjoyment of citizens' personal rights and liberties. ${ }^{2}$ This goes so far as to allow, under certain conditions, for individual views to override the interests of society - for instance in the case of a Jehovah's Witness refusing to undergo a life-saving blood transfusion, against the interest of the state to protect her. ${ }^{3}$

In Europe, on the other hand, Constitutional Courts usually give priority to well-established public order principles that safeguard the values deemed most important by the states. This is especially true in civil law countries, such as France or Belgium, which strictly uphold principles like the unavailability of the human body, whereas the legal status of human body parts remains unclear in common law countries ${ }^{4}$. However, this lack of consensus seems to be progressively fading as a result of the significant changes in society's attitude towards the human body, which are crystallised in the recent case law of the European Court of Human Rights (ECtHR). ${ }^{5}$

Indeed, starting in the 1960's, the last decades of the $20^{\text {th }}$ century saw growing calls for political liberalisation and expanded civic rights by large population groups throughout Europe. A shift in mentality

2 Griswold v Connecticut, 381 US 479 (1965), in which the Court ruled that a Connecticut law prohibiting access to contraception violated a woman's right to privacy.

3 See Munn v Southern Health Plan, Inc, 719 F Supp 525 (1989); see also Geraldine Koeneke Russell \& Donald Wallace, 'Jehovah's Witnesses and the Refusal of Blood Transfusions: A Balance of Interests' (2017) 33 The Catholic Lawyer 361

4 Thérèse Callus, 'A Pragmatic Approach to Protecting the Human Body in English Law' in Brigitte Feuillet-Liger, Geneviève Schamps \& Kristina Orfali (eds), Protecting the Human Body: Legal and Bioethical Perspectives From Around the World (Bruylant 2016); Thérèse Callus, 'Le mythe du principe de non-patrimonialité du corps humain en droit anglais : un droit ambivalent' in Brigitte Feuillet-Liger, Geneviève Schamps \& Kristina Orfali (eds), La non-patrimonialité du corps humain : du principe à la réalité (Bruylant 2017) [to be translated]

5 The landmark cases in this regard are Pretty $v$ UK ECHR 2002-III 155 and Christine Goodwin V UK ECHR 2002-VI 2

6 Pretty [61]; The wording 'personal autonomy' can be found in the English version of previous cases, but its French equivalent 'autonomie personnelle' was always omitted in official French translations until Pretty $\vee$ UK.

7 Evans v UK ECHR 2007-I 353 [71]

8 Debra Whitman, Jeffrey Love, G. Rainville, Laura Skufca, Simone Schuerle, Daphne Bavelier \& Corinna Lathan, 'What Americans Think of Human Enhancement Technologies' (Scientific American, 16 January 2018) <https://blogs.scientificamerican.com/ observations/what-americans-think-of-human-enhancement -technologies/> accessed 15 September 2018

9 Preamble to the Constitution of the World Health Organization, opened to signature in New York on 22 July 1946 and entered into force on 7 April 1948 <http://www.who.int/governance/eb/ who_constitution_en.pdf > accessed 15 September 2018 took place, as the eagerness for individual self-governance rose and the prevalence of conformist ideas declined. Accordingly, the ECtHR, undeniably inspired by the American right to privacy, began interpreting more broadly the scope of Article 8 of the European Convention on Human Rights; in 2002, the legal notion of personal autonomy was born. ${ }^{6}$ The case of Pretty $v$ the United Kingdom, also known as the right-to-die case, marked the first step of a spectacular rise of this notion, which the ECtHR even ended up acknowledging as a right. ${ }^{7}$

Personal autonomy, understood as a right to make choices about one's own body, is a prerequisite to freely use HETs in modern democracies. It certainly is a powerful tool for those advocating a right to full self-sovereignty or self-determination. But most importantly in our case, it may function as a strong vector for normalising the use of emerging or innovative technologies within the human body. Our limbs are becoming increasingly shaped by and intertwined with technology; whether we seek convenience, customisation or performance, it is undoubtedly the path we as a society have embraced. Yet oddly enough, the term 'enhancement' remains largely unknown to the broader public. ${ }^{8}$ This comes as no surprise, since today most HETs are merely diverted uses of medical treatments.

\section{The Therapy vs Enhancement Distinction}

No one would dispute the fact that therapeutic treatments play a major role in sustaining good health. When we are struck with illness or when our physician spots something unusual in our blood test, we resort to treatments in order to help restore our metabolism to its normal workings. The reason for using HETs, on the contrary, is to bring the capabilities of our body or mind beyond their ordinary level; however, this does not necessarily correlate into an uplift in baseline health measurements. This could imply that HETs are somehow dissociated from the concept of health as we commonly perceive it, making them seem like a commodity product. But what does it actually mean to be healthy?

According to the World Health Organization, health is 'a state of complete physical, mental and social well-being and not merely the absence of disease or infirmity. ${ }^{9}$ This definition provides the advantage 
of not making good health depend on an arbitrarily settled concept of normalcy. There is no such thing as a normal state of health, simply because each person (and, more broadly, each organism) comes with a different set of biologic features and operates in a different environment. ${ }^{10}$ This was emphasised by the UN Committee on Economic, Social and Cultural Rights in its General Comment No. 14: The Right to the Highest Attainable Standard of Health (Article 12), stating that this standard 'takes into account both the individual's biological and socio-economic preconditions and a State's available resources.'.11

Despite these explanations, sceptics were quick to draw an impermeable border between HETs and therapeutic treatments, arguing that the former was ethically dubious and the latter completely fine. Using such a shortcut proves problematic, and expert panels on both sides of the Atlantic agreed that this view failed to consider many parameters. In the US, former President George W Bush's Council on Bioethics released a report titled 'Beyond Therapy: Biotechnology and the Pursuit of Happiness' which deconstructed this somewhat artificial moral distinction. ${ }^{12}$ Similarly, a 2009 study commissioned by the European Parliament's Science and Technology Options Assessment (STOA) panel explicitly addressed the issue, pointing out that while there are certain characteristics that do fundamentally differ from one to the other, HETs and therapies increasingly tend to overlap. ${ }^{13}$

Nevertheless, even though it may appear as a false dichotomy, it is important to bear in mind that HETs and therapies serve a separate purpose, as the first aims to improve the capabilities of the body and the second aims to restore health. Keeping a clear distinction is essential if we are to define a framework for HETs, with significant cultural, ethical and social implications for individuals as well as for policymakers. That being said, both disciplines will inevitably feed from each other, learning lessons and sparking ideas. Technologies that have potential applications for HETs can help reinvent traditional therapies and push forward the overall state of medicine.

For instance, the onset of illness is currently the starting point of the treatment process. But the emergence of $\mathrm{P}_{4}$ medicine (predictive, preventive, personalised and participatory) may change the way we conceive healthcare and radically transform medical systems. ${ }^{14}$ The idea underlying $\mathrm{P}_{4}$ medicine is that studying a person's genetic susceptibilities along with their lifestyle and social environment could al- low for the detection of illness before it even appears, thus facilitating its 'treatment'.

Genomics - the study of complex sets of genes and how they interact with each other and with their environment ${ }^{15}$ - will play a key role in this new paradigm. Advances in the fields of computer technology and DNA sequencing techniques have allowed for its rapid development, opening up possibilities for population-wide research and original public health initiatives. But at the same time that opportunities arise, other types of risks are looming. The big data needed to effectively use genomic tools could be diverted, and genomic data privacy is a topic that most certainly will fuel heated discussions in the near future.

\section{Genetics and the Law}

At a different scale, our knowledge and mastery of genetics have also considerably expanded. This unfortunately comes with a set of drawbacks; I will focus specifically on two issues, namely genetic discrimination and controversies surrounding the alteration of one's genetic fingerprint.

\section{Genetic Discrimination}

In the context of HETs and because they are intrinsically linked to predictions as well as measurements

10 Isabel Karpin \& Roxanne Mykitiuk, 'Going Out on a Limb: Prosthetics, Normalcy and Disputing the Therapy/Enhancement Distinction' (2008) 16 Med L Rev 413

11 UN Committee on Economic, Social and Cultural Rights, General Comment No 14: The Right to the Highest Attainable Standard of Health (Art 12 of the Covenant) [2000] UN Doc E/C12/2000/4, para $9<$ https://www.refworld.org/docid/4538838d0.html> accessed 15 September 2018

12 The President's Council on Bioethics, Beyond Therapy: Biotechnology and the Pursuit of Happiness (Regan Books 2003)

13 Christopher Coenen, Mirjam Schuijff, Martijntje Smits, Pim Klaassen, Leonhard Hennen, Michael Rader \& Gregor Wolbring 'Human Enhancement' [2009] Science and Technology Options Assessment Study, $16 \mathrm{ff}<\mathrm{http} / /$ www.europarl.europa.eu/stoa/en/ document/IPOL-JOIN_ET(2009)417483> accessed 15 September 2018

14 Mauricio Flores, Gustavo Glusman, Kristin Brogaard, Nathan D Price \& Leroy Hood, 'P4 Medicine: How Systems Medicine Will Transform the Healthcare Sector and Society' (2013) 10 Personalized Medicine 565

15 Clarissa Allen, Karine Sénécal \& Denise Avard, 'Defining the Scope of Public Engagement: Examining the "Right Not to Know" in Public Health Genomics' (2014) 42 JL Med \& Ethics 11 
of performance, the sectors of employment and insurance are particularly exposed to high risks of discrimination. Genetic discrimination is nothing new: a 1992 study conducted by a team of American scientists showed that after taking genetic tests, individuals labelled with genetic conditions suffered stigmatisation and were denied basic services such as insurance coverage or adoption requests, even if the individuals concerned were asymptomatic or merely harboured disease-associated genes. ${ }^{16}$

In employment matters, genetic screening could potentially lead employers to only hire workers whose genetic constitution shows that they are at low risk of falling sick, and discard all the others who were less fortunate at birth. On the flip side, genetic monitoring might prove useful in a work environment where the employees need to handle toxic products that can influence genetic features, for their own safety but also for that of their co-workers or third parties. ${ }^{17}$ With respect to insurance however, it seems that no one is winning: insurers would evidently raise premiums of persons at risk (or default premiums in case you refuse to hand out your genetic test), whereas policyholders would knowingly hide or forge their results. Low risk individuals might even

16 Paul R Billings, Mel A Kohn, Margaret de Cuevas, Jonathan Beckwith, Joseph S Alper and Marvin R Natowicz, 'Discrimination as a Consequence of Genetic Testing' (1992) 50 Am J Hum Genet 476

17 Heleen L Janssen 'Genetic Information in European States' in Janneke H Gerards, Aalt W Heringa \& Heleen L Janssen (eds), Genetic Discrimination and Genetic Privacy in a Comparative Perspective (Intersentia 2005) 49

18 Genetic Information Nondiscrimination Act of 2008, Pub L 110-233, 122 Stat 881 (2008), Sec 101 (d) (1) \& 202 (b)

19 The Council of Europe, not to be confused with the Council of the European Union or with the European Council, is an international organisation composed of 47 member states and tasked with the promotion of human rights in Europe. It notably drafted the European Convention on Human Rights and established the European Court of Human Rights.

20 Convention on Human Rights and Biomedicine, opened to signature in Oviedo on 4 April 1997 and entered into force on 1 December 1999, arts 10-12 <https://www.coe.int/en/web/conventions/ full-list/-/conventions/treaty/164> accessed 15 September 2018

21 Council of Europe, Committee of Ministers (2016), Recommendation $\operatorname{Rec}(2016) 8$ to member states on the processing of personal health-related data for insurance purposes, including data resulting from genetic tests, 26 October 2016; Council of Europe, Committee of Ministers (2015), Recommendation Rec(2015)5 to member states on the processing of personal data in the context of employment, 1 April 2015

22 Regulation (EU) 2016/679 of the European Parliament and of the Council of 27 April 2016 on the protection of natural persons with regard to the processing of personal data and on the free movement of such data, and repealing Directive 95/46/EC (General Data Protection Regulation) [2016] OJ L119, art 9 decide to opt out of the insurance market and cover their own expenses. By taking out the uncertainty factor, the very principle of the insurance contract risk pooling - becomes compromised.

HETs do not per se create genetic discrimination - this phenomenon does not necessarily correlate with the mainstreaming of HETs - however, they might amplify the divide between the genetically strong or those who can afford an enhancement, and those who cannot. Genetics are becoming a new marker for discrimination and HETs will potentially play a part in increasing wealth disparities in the coming years. The question, then, is what can we do about it?

The answer probably lies in the protection of individual genetic data and limitation of access to this data by unauthorised parties. But the situation is made trickier by the fact that genetic data is partly shared between members of the same family; disclosure of one member's genetic information can lead to a breach of the others' genetic privacy. The problem was explicitly addressed in the US, where Congress passed the Genetic Information Nondiscrimination Act (GINA) in 2008. GINA expressly prohibits employers and insurers from requesting or purchasing genetic information pertaining to individuals concerned or their family members. ${ }^{18}$ In Europe, the Convention on Human Rights and Biomedicine (Oviedo Convention), binding on those member states of the Council of Europe $(\mathrm{CoE})^{19}$ that have ratified it, ensures the respect of the principles of confidentiality as well as non-discrimination on grounds of genetic heritage, and narrows circumstances in which predictive genetic tests may be performed. ${ }^{20}$ Non-binding instruments, such as the 2016 Recommendation on data resulting from genetic tests and the revised Recommendation on the processing of personal data in the context of employment, are based on the same approach. ${ }^{21}$ In the European Union's legal system, genetic information qualifies as sensitive data under Article 9 (1) of the General Data Protection Regulation (GDPR), which makes it prohibited to process unless specifically authorised under Article $9(2){ }^{22}$

\section{Alteration of One's Genetic Fingerprint}

Perhaps even more contentious than control over our bodies is the subject of control over our genetic material. Genetic engineering is technically very much 
feasible today, only for now it is exclusively used for research and strictly therapeutic purposes. Nevertheless, medical acts affecting our genome are slowly becoming trivialised, paving the way for wider acceptance of genetic enhancement. Sometimes, personal autonomy is invoked to justify freely disposing of one's genetic material, as in the case of a woman willing to donate her frozen embryos to scientific research. ${ }^{23}$ Other times, a breakthrough in gene therapy will make it possible to cure (or at least mitigate) a disease refractory to more traditional therapies. ${ }^{24}$ In the latter instance, a person's genes are directly altered. This can be done in two ways: either via somatic gene therapy, whereby only the genetic material of body cells is being modified, or germline gene therapy, which targets the gametes. ${ }^{25}$

It follows that somatic gene therapy affects only the individual undergoing treatment, whereas the effects of germline gene therapy - or enhancement will be passed on to their offspring. From a legal standpoint, ethical conundrums aside, somatic gene therapy is perfectly fine. The status of germline gene therapy, on the other hand, is unclear. As of today, no universally binding treaty dealing with the matter exists, which leaves it up to the states. In the US, human germline modification is de facto banned as a result of a rider on the Consolidated Appropriations Act of 2016, even though no federal legislation expressly prohibits it. ${ }^{26}$ In Europe, the Oviedo Convention stipulates that interventions seeking to modify the human genome may not aim to introduce any modification in the genome of any descendants, but states that have not ratified it remain free to legislate as they see fit. $^{27}$

If germline gene therapy could theoretically eradicate over the span of one generation most hereditary disorders, some fear that it would rapidly turn into a way to create 'designer babies' or to promote eugenics. Proponents of those concepts may argue that genetically enhancing the future child is in his best interest, since he will be able to become virtually anything in life. ${ }^{28}$ However, such a view fundamentally disregards the potentially disastrous psychological consequences that the genetically engineered child might face, not to mention the unknown side effects germline gene therapy could show in the longer term. In the end it all boils down to personal choice, which cannot be made by the parents. Along the same lines, the Parliamentary Assembly of the $\mathrm{CoE}$ as well as a handful of legal scholars have put forth the idea of a right to a genetic inheritance which has not been artificially interfered with, either to the benefit of the child once he is born (embryos, as a rule, do not enjoy legal personality) ${ }^{29}$ or to the benefit of mankind as a whole. ${ }^{30}$

\section{Conclusion}

For better or worse, the world around us is constantly evolving. The pace is fast, and HETs are one of many emerging technologies that are bound to expand globally. Our society reflects our aspirations; ${ }^{31}$ and it shows signs that we are longing for more autonomy in our life choices and in the way we make them. The focus has shifted from the protection of conservative values to the fostering of personal growth and self-fulfilment.

HETs also make us question seemingly obvious constructs such as the notion of health. We may be approaching a medical revolution, a new era that comes with its opportunities and risks. Progress in genetics and genomics could improve the living conditions of millions, as much as they could create a pervasive form of social Darwinism. The development of HETs raise a number of issues that are at the

23 See the Dissenting Opinion of Judge Sajó in Parrillo v Italy ECHR 2015-V 249

24 Eric A Pierce and Jean Bennett 'The Status of RPE65 Gene Therapy Trials: Safety and Efficacy' (2015) 5 Cold Spring Harb Perspect a017285

25 To go further, see Michael H Shapiro 'Does Technological Enhancement of Human Traits Threaten Human Equality and Democracy?' (2002) 39 San Diego L Rev 769

26 Joshua D Seitz 'Striking a Balance: Policy Considerations for Human Germline Modification' (2018) 16 Santa Clara J Int'I L. 60,73

27 Convention on Human Rights and Biomedicine, art 13

28 Supporters of this view often base their claims on the works of philosopher Joel Feinberg, who coined the term "child's right to an open future" in his eponymous essay; see Joel Feinberg 'The Child's Right to an Open Future' in William Aiken \& Hugh LaFollette (eds), Whose Child? Children's Rights, Parental Authority and State Power (Rowman and Littlefield 1980).

29 Vo v France ECHR 2004-VIII 67 [84-85]; Bernard M Dickens, Rebecca J Cook 'The Legal Status of In Vitro Embryos' (2010) 111 International Journal of Gynecology and Obstetrics 91

30 Council of Europe, Parliamentary Assembly (1982), Recommendation Rec(1982)934 on Genetic Engineering, 26 January 1982; see also Rose-Marie Lozano, La protection européenne des droits de l'homme dans le domaine de la biomédecine (La documentation française 2001)

31 For more on this, see Armin Grunwald 'Are We Heading Towards an 'Enhancement Society'?' in Elisabeth Hildt \& Andreas G Franke (eds), Cognitive Enhancement - An Interdisciplinary Perspective (Springer 2013) 
crossroads of science, law, ethics and philosophy: are we playing God? To what degree should we apply the precautionary principle? What responsibility do we bear towards our own body? Dealing with these mat- ters is no easy feat. But it is for certain that finding the answers will require critical forward thinking as well as genuine cooperation on the international scale. 